\section{Cataract surgery complications as a cause of visual impairment in a population aged 50 and over}

\author{
Complicações de facectomias como causa de \\ baixa visual em uma população com 50 \\ ou mais anos de idade
}

\footnotetext{
${ }^{1}$ Faculdade de Ciências Médicas, Universidade Estadual de Campinas, Campinas, Brasil.

Correspondence R. P. C. Lira Departamento de Cirurgia, Faculdade de Ciências Médicas, Universidade Estadual de Campinas. Rua Irmã Maria David 200, apto. 1302, Recife, PE 52061-070, Brasil. rodrigopclira@hotmail.com
}

\begin{abstract}
The purpose of this study was to measure the extent to which complications relating to cataract surgery are a cause of visual impairment in a population aged 50 and over from the city of Campinas, São Paulo State, Brazil. An assessment of cataract surgery services was conducted using random cluster sampling, with the sample composed of 60 clusters of 40 people aged 50 years or older. Of the selected sample of 2,400 subjects, 92.67\% were examined. Of these 2,224 examined subjects, 75 (3.37\%) presented bilateral visual impairment and 164 unilateral, while a total of 314 (7.06\%) eyes presented visual impairment. 352 eyes had undergone cataract surgery. The causes of visual impairment after surgery were concurrent eye disease (56\%), surgical complications (28.8\%) and refractive errors (15.2\%). Cataract surgery complications represented the 5 th most important cause of visual impairment. The other main causes were cataract, posterior segment disorders, diabetic retinopathy and glaucoma. These results suggest cataract surgery complications are a major cause of visual impairment in this population. Their prevention and treatment must be part of public health care policies.
\end{abstract}

Blindness; Cataract; Cataract Extraction; Visual Acuity
Denise Fornazari de Oliveira 1 Rodrigo Pessoa Cavalcanti Lira 1 Álvaro Pedroso Carvalho Lupinacci 1 Marcelo Paccola 1 Carlos Eduardo Leite Arieta 1

\section{Introduction}

According to recent studies, age-related cataract is responsible for 48 per cent of blindness worldwide, representing around 18 million people. Although cataracts can be surgically removed, in many countries surgical services are inadequate, and cataract remains the leading cause of visual impairment. As people live longer, the number of people with cataract is growing. Cataract is also an important cause of low vision in both developed and developing countries. Even where surgical services are available, low vision associated with cataract may still be prevalent as a result of the long period spent waiting for operations and barriers to surgical uptake, such as cost, lack of information, and transportation problems 1 .

The most important causes of adult visual impairment in Brazil include cataract, glaucoma, retinal diseases and non-corrected refractive errors. Cataract accounts for between 40 and 50 per cent of the cases despite the many efforts that have been made over the past five years ${ }^{2}$.

Although it is widely recognized that cataract extraction and intraocular lens implantation is highly effective and successful, complications due to cataract surgery can result in significant visual impairment as well as additional health care costs 3 . Other causes of poor outcome may be concomitant pathology or uncorrected refractive error 4 
The Rapid Assessment of Cataract Surgical Services (RACSS) is a protocol that can generate several reports including: prevalence of visual impairment, visual outcome after cataract surgery and major causes of poor visual outcome. There are many examples of RACSS surveys $5,6,7,8,9$.

The objective of this study was to measure the contribution made by cataract surgery complications in causing visual impairment in a population aged 50 and over from Campinas, São Paulo State, Brazil.

\section{Methods and population}

\section{Population}

According to data from the Brazilian Population Survey, Campinas has 969,396 inhabitants in an area of $801 \mathrm{~km}^{2} 10$. The sampling frame was formed from the list of all enumeration areas of Campinas included in this survey, as published in the CD-ROM 10. A column with the cumulative population was added to this list and from this column, 60 clusters were selected using random sampling. This provides a random selection with a probability proportional to the population size. In each cluster 40 people aged 50 and over were to be examined. In the year 2000, there were a total of 174,811 people aged 50 or older in Campinas, of which 2,400 had to be examined. The RACSS method was followed 8 .

The sample size of 2,400 was powerful enough to assess and confirm the expected prevalence of $3 \%$ of people with bilateral cataract visual impairment (visual acuity $<6 / 60$ with available correction), with a variation between $3.7 \%$ and $2.3 \%$, and a confidence interval of $90 \%$. The study was approved by the Ethics Committee of the University of Campinas (UNICAMP) Medical School. The subjects, who were examined free of charge, agreed to participate in the study and signed an informed consent form.

\section{Examination and field work}

Visual acuity is written as a fraction. The number in the numerator position represents the test distance in meters between the eye and the chart being used. The number in the denominator position is the distance at which the subject can read the same figure. This notation quantifies visual discrimination of fine detail. Visual acuity was measured using a tumbling Snellen "E" chart letter of size 60 on one side and size 18 on the other side, at six and three meters. The test took place on the street in front of the peoples' houses, at daylight. Visual acuity was measured for each eye and the smaller letter chart was shown when the bigger could be seen. Visual acuity was assessed with a pinhole when it was less than $3 / 18$, to detect if low vision was due to refractive errors. Patients were interviewed in a shaded place by means of eye examination with a torch, binocular loupe and direct ophthalmoscopy; no dilation of the pupil was used. The examination was performed as in other RACSS studies 5,6,7,8,9.

\section{$\underline{\text { Data }}$}

The input of data on the appropriate form was performed by one of the ophthalmologists. The forms were entered into a special software program, RACSS version 2.02 for Windows (World Health Organization/International Agency for the Prevention of Blindness, Geneva, Switzerland). The following reports were chosen: prevalence of visual impairment, visual outcome of cataract surgery and major causes of poor visual outcome. Further customized analysis was possible using the analysis facilities of Epi Info (Centers for Disease Control and Prevention, Atlanta, USA).

\section{Results}

From the target study population of 2,400 , a total of 2,224 participants could be examined, representing coverage of $92.67 \%$, with a mean age of $64 \pm 12$ years. The gender distribution was $42.04 \%$ (935) males and $57.96 \%(1,289)$ females. Of the population expected to be examined, 134 were not available and 42 refused the examination.

Of the 2,224 examined subjects, 75 (3.37\%) presented bilateral visual impairment, 164 presented unilateral visual impairment and a total of $314(7.06 \%)$ eyes presented visual impairment (Table 1).

Patients who had previously been operated (a total of 229 persons with 352 operated eyes) all had their visual acuity measured. Of these, 328 eyes (93.2\%) underwent surgery with placement of an intraocular lens (Table 2). The causes of visual impairment after surgery were concurrent disease in 37 eyes (56\%), surgical complications in 19 eyes (28.8\%) and refractive errors in 10 eyes $(15.2 \%)$

\section{Discussion}

In the present study, bilateral visual impairment was found in $3.37 \%$ and unilateral in $7.06 \%$ of the study population. Cataract surgery complications were the $5^{\text {th }}$ most important cause of 
Cause of visual impairment. Campinas, São Paulo State, Brazil, 2004.

\begin{tabular}{|c|c|c|c|c|}
\hline \multirow[t]{2}{*}{ Cause } & \multicolumn{2}{|c|}{ Persons * } & \multicolumn{2}{|c|}{ Eyes ** } \\
\hline & $\mathbf{n}$ & $\%$ & $\mathbf{n}$ & $\%$ \\
\hline Cataract & 32 & 42.6 & 117 & 37.2 \\
\hline Refractive error & 2 & 2.7 & 10 & 3.2 \\
\hline Uncorrected aphakia & 0 & 0.0 & 4 & 1.3 \\
\hline Cataract surgical complication & 3 & 4.0 & 19 & 6.1 \\
\hline Phthisis bulbi & 0 & 0.0 & 12 & 3.8 \\
\hline Trachoma corneal opacity & 0 & 0.0 & 1 & 0.3 \\
\hline Other corneal opacity & 1 & 1.3 & 12 & 3.8 \\
\hline Glaucoma & 6 & 8.0 & 20 & 6.4 \\
\hline Diabetic retinopathy & 11 & 14.7 & 28 & 8.9 \\
\hline Macular degeneration & 2 & 2.7 & 7 & 2.2 \\
\hline 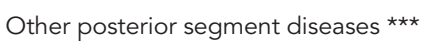 & 18 & 24.0 & 84 & 26.8 \\
\hline Not examined & 0 & 0.0 & 0 & 0.0 \\
\hline Total & 75 & 100.0 & 314 & 100.0 \\
\hline
\end{tabular}

* Bilateral visual acuity < 6/60 (with available correction);

** Total number of eyes with visual acuity $<6 / 60$ including persons with bilateral visual impairment;

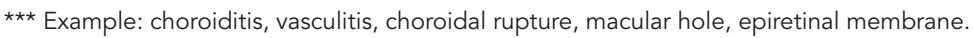

Postoperative visual acuity of the operated eyes in the sample (with available correction or pinhole). Campinas, São Paulo State, Brazil, 2004

\begin{tabular}{|c|c|c|c|c|c|c|}
\hline & \multicolumn{2}{|c|}{$\begin{array}{c}\text { Cataract surgery } \\
\text { without } \\
\text { intraocular lens } \\
\text { implantation }\end{array}$} & \multicolumn{2}{|c|}{$\begin{array}{l}\text { Cataract surgery } \\
\text { with intraocular } \\
\text { lens implantation }\end{array}$} & \multicolumn{2}{|c|}{ Total } \\
\hline & n & $\%$ & $\mathbf{n}$ & $\%$ & $\mathbf{n}$ & $\%$ \\
\hline \multicolumn{7}{|l|}{ Category of visual acuity } \\
\hline Can see 6/18 & 6 & 25.0 & 237 & 72.2 & 243 & 69.0 \\
\hline Cannot see $6 / 18$, can see $6 / 60$ & 5 & 20.8 & 38 & 11.6 & 43 & 12.2 \\
\hline Cannot see $6 / 60$ & 13 & 54.2 & 53 & 16.2 & 66 & 18.8 \\
\hline Total & 24 & 100.0 & 328 & 100.0 & 352 & 100.0 \\
\hline
\end{tabular}

visual impairment. They were responsible for the impairment in $4 \%$ of participants and $6.1 \%$ of the eyes. The other most important causes of visual impairment in order of significance were cataract, posterior segment diseases (including macular diseases but not senile macular degeneration), diabetic retinopathy and glaucoma.

Surgery only plays a small part in the cure of cataract. Much of what has happened in the last 15 years has been driven by the need for greater surgical output, a need that is met relatively eas- ily, rather than by a regard for vision outcomes and rehabilitation. Concern with auditing outcomes and assuring quality is a relatively recent phenomenon. It has come to show that despite all the attention given to cataract surgical detail, postoperative vision results are less positive, and complication rates greater than anticipated 11 . For example, an assessment of cataract surgery in India showed that $21 \%$ of patients had a very poor outcome (presenting visual acuity $<6 / 60$ ), with another $35 \%$ having poor outcomes $(6 / 18$ 
to $6 / 60) 12$. In neighboring Nepal, $21 \%$ are even blind postoperatively, presenting a visual acuity of $<6 / 60$ in both eyes. However, this improves to $7 \%$ with best correction 13,14 .

A population-based survey in KwaZulu-Natal showed that a campaign to increase cataract surgery had little effect on the prevalence of blindness, but shifted the etiology from cataract to uncorrected aphakia 15. A high priority for cataract surgery must be to make intraocular lens implantation a routine part of cataract surgery, and to encourage prospective monitoring of outcomes in order to improve surgical results 4,16. Further improvements can be achieved by ensuring that patients are refracted following surgery, and that they are provided with glasses to correct residual refractive error 17 . The greatest challenge for ophthalmologists, policy-makers, donors, and researchers is not developing new techniques or treatments, but ensuring that the high standards of both output and outcome that are currently manifest in some centers become the norm 17. A survey at the State University of Campinas demonstrated that good quality surgery may improve vision status in $92.8 \%$ of blind patients 18 .

Our study had some limitations. For example, the frequency of postoperative cataract complications varies from between $0.13 \%$ for endophthalmitis to $19.7 \%$ for posterior capsule opacification ${ }^{3}$. A limitation of this manuscript is that it studies the presence or absence of cataract complications but not each one individually because RACSS was designed to study the global frequency. Another limitation is the eye examination method, non-dilated direct ophthalmoscopy, which limits the diagnosis. The dilatation of the pupil and use of other basic equipment such as the slit lamp and the applanation tonometer would give more precision to the results. However the RACSS methods used in this study are standardized and were previously tested and approved, and its results are comparable to those found around the world 5,6,7,8,9.

To improve the outcome of our cataract surgery the following should be applied: (1) cataract surgeons must monitor their intraoperative complications and the visual outcome of their surgery; (2) program managers must ensure adequate training of cataract surgeons, ensure provision of adequate instrumentation and required surgical consumables and ensure that all cataract surgeons are monitoring the outcome of their surgeries 4 .

\section{Conclusion}

Cataract surgery complications are a major cause of visual impairment in the over-50 population in Campinas. Their prevention and treatment must be included in public health care policies.

\section{Resumo}

Objetivou-se avaliar a relevância das complicações de facectomias como causa de baixa acuidade visual na população $\geq 50$ anos em Campinas, São Paulo, Brasil. Uma avaliação dos serviços de cirurgia de catarata foi conduzida utilizando amostragem aleatória de agrupamentos populacionais, sendo composta por 60 agrupamentos de 40 pessoas $\geq 50$ anos. Na amostra de 2.400 indivíduos, 92,67\% foram examinados. Dos 2.224 examinados, 75 (3,37\%) apresentaram baixa acuidade visual bilateral, 164, unilateral. e um total de 314 (7,06\%) olhos apresentou baixa acuidade visual. Trezentos e cinqüenta e dois olhos tinham sido submetidos a facectomias. As causas de baixa acuidade visual pós-cirurgia foram doenças oculares con- comitantes (56\%), complicações cirúrgicas $(28,8 \%) e$ erros refrativos $(15,2 \%)$. Complicações de cirurgias de catarata foram a quinta causa mais importante de baixa acuidade visual. Outras causas principais foram catarata, doenças oculares do segmento posterior, retinopatia diabética e glaucoma. Estes resultados sugerem que complicações de cirurgias de catarata é uma importante causa de baixa acuidade visual na população em estudo. Sua prevenção e tratamento precisam fazer parte das políticas de saúde pública.

Cegueira; Catarata; Extração de Catarata; Acuidade Visual 


\section{Contributors}

D. F. Oliveira and C. E. L. Arieta participated in the research design, data collection and analysis, manuscript review and final draft of the article. R. P. C. Lira participated in the research design, data analysis, manuscript review and final draft of the article. A. P. C. Lupinacci and M. Paccola participated in the research design, data collection and analysis, and final draft of the article. C. E. L. Arieta participated in the research design, data collection and analysis, manuscript review and final draft of the article.

\section{Acknowledgments}

Hans Limburg collaborated intellectually in giving scientific advice and critical review of the research. Juan Carlos Silva (Pan-American Health Organization): partial funding.

\section{References}

1. World Health Organization. Prevention of blindness and visual impairment: cataract. http://www. who.int/blindness/causes/priority/en/index1. html (accessed on 10/Mar/2007).

2. Arieta CEL, Delgado AMN, José NK, Temporini ER, Alves MR, Moreira Filho DC. Refractive errors and cataract as causes of visual impairment in Brazil. Ophthalmic Epidemiol 2003; 10:15-22.

3. Powe NR, Schein OD, Gieser SC, Tielsch JM, Luthra $\mathrm{R}$, Javitt J, et al. Synthesis of the literature on visual acuity and complications following cataract extraction with intraocular lens implantation. Arch Ophthalmol 1994; 112:239-52.

4. Cook CD. How to improve the outcome of cataract surgery. Community Eye Health 2000; 13:37-8.

5. Amansakhatov S, Volokhovskaya ZP, Afanasyeva AN, Limburg H. Cataract blindness in Turkmenistan: results of a national survey. Br J Ophthalmol 2002; 86:1207-10.

6. Duerksen R, Limburg H, Carron JE, Foster A. Cataract blindness in Paraguay: results of a national survey. Ophthalmic Epidemiol 2003; 10:349-57.

7. Haider S, Hussain A, Limburg H. Cataract blindness in Chakwal District, Pakistan: results of a survey. Ophthalmic Epidemiol 2003; 10:249-58.

8. Limburg H, Kumar R, Indrayan A, Sundaram KR. Rapid assessment of prevalence of cataract blindness at district level. Int J Epidemiol 1997; 26: 1049-54.

9. Pongo Aguila L, Carrion R, Luna W, Silva JC, Limburg H. Cataract blindness in people 50 years old or older in a semirural area of northern Peru. Rev Panam Salud Pública 2005; 17:387-93.
10. World Bank. World development indicators 2001 [CD-ROM]. Washington DC: World Bank; 2001.

11. Brian G, Taylor H. Cataract blindness: challenges for the 21st century. Bull World Health Organ 2001; 79:249-56.

12. Dandona L, Dandona R, Naduvilath TJ, McCarty CA, Mandal P, Srinivas M, et al. Population-based assessment of the outcome of cataract surgery in an urban population in Southern India. Am J Ophthalmol 1999; 127:650-8.

13. Pokharel GP, Selvaraj S, Ellwein LB. Visual functioning and quality of life outcomes among cataract operated and unoperated blind populations in Nepal. Br J Ophthalmol 1998; 82:606-10.

14. Pokharel GP, Regmi G, Shrestha SK, Negrel AD, Ellwein LB. Prevalence of blindness and cataract surgery in Nepal. Br J Ophthalmol 1998; 82:600-5.

15. Cook CD, Stulting AA. Impact of a sight-saver clinic on the prevalence of blindness in northern KwaZulu. S Afr Med J 1995; 85:28-9.

16. Yorston D. Are intraocular lenses the solution to cataract blindness in Africa? Br J Ophthalmol 1998; 82:469-71.

17. Yorston D, Abiose A. Cataract blindness: the African perspective. Bull World Health Organ 2001; 79:257-8.

18. Abujamra MN, Lira RPC, Soares PHL, Spessato N, José NK, Arieta CEL. Are routine preoperative medical tests needed with cataract surgery? Study of visual acuity outcome. Curr Eye Res 2004; 28:285-90

Submitted on 19/Mar/2007

Final version resubmitted on 06/Dec/2007 Approved on 14/Jan/2008 